\title{
Resepsi Al-Qur'an Di Pondok Pesantren Al-Hidayah Karangsuci Purwokerto
}

\author{
Akhmad Roja Badrus Zaman \\ UIN Sunan Kalijaga \\ Jl. Daendeles RT 4 RW 3 Desa Mujur Lor, Kec. Kroya, Kab. Cilacap 53126 \\ E-mail: badruszamana@gmail.com
}

\begin{abstract}
Abstrak:
Al-Qur'an sejatinya merupakan kitab suci yang berisi ajaran-ajaran moral untuk menuntun manusia ke jalan yang lurus. Hanya saja, ketika Al-Qur'an di konsumsi oleh publik, kitab tersebut mengalami pergeseran paradigma sehingga diperlakukan, diresepsi, dan diekspresikan berbeda-beda sesuai dengan pengetahuan dan keyakinan masing-masing. Ekspresi tersebut, tentu merupakan indikator konkret bahwa Al-Qur'an merupakan kitab suci yang senantiasa selaras dengan segala situasi dan kondisi (șālih li kulli zamān wa makān). Model dan gaya resepsi tersebut bahkan kini terus diekspresikan dan dilestarikan oleh keluarga besar Ponpes Al-Hidayah Karangsuci Purwokerto. Penelitian ini bertujuan untuk mengetahui ragam resepsi AlQur'an yang ada di Ponpes tersebut, serta berusaha memahami makna yang melekat di dalamnya. Penelitian ini dirancang dengan metode kualitatif dan termasuk dalam penelitian lapangan. Dalam memperoleh data, instrumen yang peneliti gunakan adalah wawancara mendalam, observasi, dan studi atas dokumen terkait. Analisis yang digunakan peneliti adalah sebagaimana yang disampaikan Mohd. Soehadha, yaitu dengan reduksi data, display data, dan penarikan kesimpulan. Di dalam mengklarifikasi keabsahan data, peneliti melakukan perpanjangan keikutsertaan, dan triangulasi sumber maupun metode. Dari penelitian yang dilakukan, didapatkan hasil antara lain: (1) ragam resepsi Al-Qur'an yang ada di Ponpes Al-Hidayah Karangsuci Purwokerto, (2) Adapun makna-makna yang melekat dalam ragam resepsi tersebut, antara lain: makna objektif, makna ekspresif, dan makna dokumenter. Makna objektif menyimpulkan bahwa ragam perilaku resepsi di ponpes tersebut adalah sebagai simbolisasi kepatuhan dan ketakziman terhadap peraturan pondok. Makna ekspresifnya adalah sebagai wujud internalisasi diri dengan hal-hal positif melalui proses pembelajaran Al-Qur'an yang berkelanjutan, dan makna dokumenternya adalah sebagai bentuk kontekstualisasi lokal dari sistem kebudayaan yang menyeluruh.
\end{abstract}

\section{Kata Kunci: Resepsi, Al-Qur’an, Ponpes Al-Hidayah, Karangsuci.}

\section{Abstract:}

The Qur'an is truly a holy book containing moral teachings to guide people to the straight path. It's just that, when the Qur'an is consumed by the public, the book experiences a paradigm shift so that it is treated, received, and expressed differently according to their respective knowledge and beliefs. That expression, of course, is a concrete indicator that the Qur'an is a holy book which is always in harmony with all situations and conditions (șālih li 
kulli zamān wa makān). The model and style of the reception even now continue to be expressed and preserved by the family of Ponpes Al-Hidayah Karangsuci, Purwokerto. This study aims to determine the variety of AlQur'an receptions in Ponpes and try to understand the meaning inherent in it. This research was designed with qualitative methods and included in field research. In obtaining data, the instruments that researchers use are in-depth interviews, observations, and studies of related documents. The analysis used by researchers is as presented by Mohd. Soehadha, namely by reducing data, displaying data, and drawing conclusions. In clarifying the validity of the data, the researcher extends the participation and triangulation of sources and methods. From the research conducted, the results obtained include: (1) a variety of Al-Qur'an receptions in the Al-Hidayah Islamic Boarding School Karangsuci Purwokerto, (2) The meanings inherent in the reception variety, among others: objective meaning, expressive meaning, and documentary meaning. The objective meaning is to conclude that the variety of reception behavior at the Islamic boarding school is a symbol of compliance and injustice to the regulations of the boarding school. The expressive meaning is a form of self-internalization with positive things through the continuous learning process of the Qur'an, and the meaning of the documentary is a form of local contextualization of the whole cultural system.

Keywords: Reception, Al-Quran, Al-Hidayah, Ponpes Karangsuci.

\section{A. Pendahuluan}

$\mathrm{M}$ engkaji fenomena keagamaan berarti mempelajari perilaku manusia dalam kehidupan beragama. Sedangkan fenomena keagamaan itu sendiri adalah perwujudan sikap dan perilaku manusia yang berkaitan dengan hal-hal yang dipandang suci-dalam hal ini adalah Al-Qur'an (Sudarmoko, 2016, p. 1). Al-Qur'an pada prinsipnya adalah wahyu yang bersifat progresif (Wahid, 2016, p. 149). Progresifitas Al-Qur'an ditunjukkan dengan teks-teks yang senantiasa berdialog dengan konteks yang dihadapi.

Al-Qur'an sejatinya merupakan kitab suci yang berisi ajaran-ajaran moral untuk menuntun manusia ke jalan yang lurus. Hanya saja, ketika Al-Qur'an di konsumsi oleh publik, kitab tersebut mengalami pergeseran paradigma sehingga diperlakukan, diresepsi, dan diekspresikan berbeda-beda sesuai dengan pengetahuan dan keyakinan masing-masing. Ekspresi tersebut, tentu merupakan indikator konkret bahwa Al-Qur'an merupakan kitab suci yang senantiasa selaras dengan segala situasi dan kondisi (șālih li kulli zamān wa makān). Model dan gaya resepsi tersebut bahkan kini terus diekspresikan dan dilestarikan oleh keluarga besar Pondok Pesantren Al-Hidayah Karangsuci Purwokerto.

Dalam konteks meresepsi Al-Qur'an, para santri memiliki ekspresi yang beragam. Salah satu contoh yang bisa diangkat adalah adanya tradisi pembiasaan pembacaan surat-surat 'pilihan' (surat Al-Wāqi'ah dan surat Yāsīn). Surat Al-Wāqi'ah rutin dibaca 
oleh santri setelah selesai melaksanakan shalat ashar berjamaah, sedangkan surat Yāsīn rutin dibaca setelah melaksanakan shalat maghrib berjamaah. Tradisi ini dilakukan secara komunal dengan dipimpin oleh seorang imam, yang ditunjuk oleh pihak pengasuh.

Hal lain yang menarik untuk diangkat adalah adanya santri yang meresepsi kehadiran Al-Qur'an dengan cara yang estetik, yakni dengan menjadikannya kaligrafi yang diletakkan di berbagai tempat, seperti asrama santri dan ndalem pengasuh. ${ }^{1}$ Selain itu di Ponpes Al-Hidayah Karangsuci Purwokerto ini, Al-Qur'an juga diresepsi melalui pengajian rutin Kitab Tafsīr Jalalain, dan juga diresepsi oleh para santri dengan berbagai kegiatan preservasi Al-Qur'an semisal hafalan, simā'an, dan murāja'ah.

Penelitian ini bertujuan untuk mengetahui ragam resepsi Al-Qur'an yang ada di Ponpes Al-Hidayah Karangsuci Purwokerto, serta berusaha memahami makna yang melekat di dalamnya. Untuk menjawab fokus pencarian makna, peneliti menggunakan teori sosiologi pengetahuan Karl Mannheim, yang difokuskan pada tiga variabel, yaitu makna objektif, makna ekspresif, dan makna dokumenter. Makna Objektif adalah makna yang ditentukan oleh konteks social dimana tindakan tersebut berlangsung. Makna Ekspresif adalah makna yang ditunjukan oleh aktor (pelaku tindakan), dan Makna Dokumenter adalah makna yang tersirat atau tersembunyi, sehingga (aktor) pelaku tindakan tersebut, tidak sepenuhnya menyadari bahwa suatu aspek yang diekspresikan menunjukkan kepada kebudayaan secara keseluruhan (Baum, 1999, pp. 15-16).

\section{B. ReSePsi Al-QuR'an Dan Makna Yang Melekat: Sebuah Tatapan EPISTEMOLOGIS}

Berbicara tentang resepsi, secara etimologis kata resepsi berasal dari bahasa Latin, 'recipere' yang berarti penerimaan atau penyambutan pembaca (Ratna, 2009, p. 22). Sedangkan definisi terminologisnya yaitu ilmu keindahan yang didasarkan pada respon pembaca terhadap karya sastra (Pradopo, 2007, p. 7). Pada awalnya, resepsi memang merupakan disiplin ilmu yang mengkaji tentang peran pembaca terhadap karya sastra. Hal ini dikarenakan karya sastra ditujukan kepada kepentingan pembaca sebagai penikmat dan konsumen karya sastra, di dalam aktivitas mengkonsumsi tersebut, pembaca menentukan makna dan nilai dari karya sastra, sehingga karya sastra mempunyai nilai, karena pembaca yang memberikan nilai. Dengan demikian, dapat

\footnotetext{
${ }^{1}$ Observasi pada Kamis. 16 September 2018
} 
dipahami bahwa teori resepsi ini adalah teori yang membahas peranan pembaca dalam menyambut karya sastra (Iser, 1978, p. 20).

Dari definisi diatas, jika dikombinasikan dengan kata Al-Qur'an, maka dapat dipahami bahwa 'resepsi Al-Qur'an' berarti kajian tentang sambutan pembaca terhadap ayat-ayat suci Al-Qur'an. Sambutan tersebut bisa berupa: (1) cara masyarakat menafsirkan pesan ayat-ayatnya, (2) cara masyarakat mengaplikasikan ajaran moralnya, serta (3) cara masyarakat membaca dan melantunkan ayat-ayatnya. Dengan demikian pergaulan dan interaksi pembaca dengan Al-Qur'an merupakan konsentrasi dari kajian resepsi ini. Implikasi dari kajian tersebut yaitu memberikan kontribusi tentang ciri khas dan tipologi masyarakat dalam bergaul dengan Al-Qur'an.

Sementara itu, jika teori resepsi pada dasarnya merupakan teori yang mengkaji peran dan respon pembaca terhadap suatu karya sastra, maka persoalan penting yang harus diselesikan apakah Al-Qur'an merupakan karya sastra? Menurut ahli sastra, suatu karya dapat tergolong sebagai karya sastra yaitu apabila mempunyai tiga elemen literariness (aspek sastra) sebegai berikut (Fathurrosyid, 2015, p. 222):

1. Estetika rima dan irama.

2. Defamiliarisasi, yaitu kondisi psikologi pembaca yang mengalami ketakjuban setelah mengkonsumsi karya tersebut.

3. Reinterpretasi, yaitu kuriositas pembaca karya sastra untuk melakukan reinterpretasi terhadap karya sastra yang telah dinikmatinya.

Dari ketiga elemen literariness diatas, kitab suci Al-Qur'an yang menggunakan media bahasa Arab juga sarat akan elemen-elemen tersebut, misalnya elemen pertama yang berbasis rima dan irama terkandung dalam Al-Qur'an surat Al-Insyirah ayat 1 sampai dengan 8 yang memiliki variasi rima yang unik. Karakteristik kebahasaan yang indah dan teratur dalam menyampaikan pesan makna yang terkandung di dalamnya menimbulkan rasa kagum terhadap psikologi pembaca dan pendengarnya (Iswatunnisa, 2015, p. xvi). Demikian pula, pada elemen defamiliarisasi di dalam diri pembaca. Begitu seseorang membaca Al-Qur'an, maka otomatis ia takjub padanya. Sayyid Qutb menyebut proses ketakjuban ini dengan istilah mashūrun bi Al-Qur'ān (tersihir oleh AlQur'an), sebagaimana yang dialami oleh Umar bin Khattab (Al-Baihāqī, 1408, v. 2, p. 199).

Selain daripada itu, proses reinterpretasi sebagai konsekuensi dari elemen ketiga juga nampak nyata dalam Al-Qur'an. Proses reinterpretasi dalam konteks ini adalah respon pembaca atau pendengar terhadap kedua elemen diatas, sehingga dalam kajian keislaman, banyak orang tertarik untuk mengkaji aspek estetika Al-Qur'an, aspek retorika, dan lain sebagainya yang nantinya akan melahirkan perilaku, tradisi, atau budaya tertentu sebagai manifestasi daripada pemahaman tersebut. 
Ahmad Rafiq dalam artikelnya "Tradisi Resepsi Al-Qur'an di Indonesia" mengatakan bahwa kajian tentang resepsi Al-Qur'an tergolong dalam kajian fungsi, yang terdiri dari fungsi informatif dan performatif. Fungsi informatif yakni ranah kajian kitab suci sebagai sesuatu yang dibaca, dipahami, dan diamalkan. Sedangkan fungsi performatif yakni ranah kajian kitab suci sebagai sesuatu yang 'diperlakukan', misal sebagai wirid untuk nderes atau bacaan-bacaan suwuk. Dari kedua fungsi ini, menurutnya pula bahwa lembaga pendidikan keagamaan sepertihalnya pesantren itu lebih cenderung kearah performatif, yang dapat dianalisa menurut tiga tipologi, antara lain (Rafiq, 2004, p. 3):

\section{Resepsi Eksegesis}

Resepsi eksegesis yakni ketika Al-Qur'an diposisikan sebagai teks yang berbahasa - Arab - dan bermakna sebagai bahasa. Resepsi eksegesis mewujud dalam bentuk penafsiran Al-Qur'an, baik bi al-lisān dan ditulis bi al-qalam. Bi al-lisān artinya Al-Qur'an ditafsirkan melalui pengajian kitab-kitab tafsir Al-Qur'an semisal kitab Tafsir Jalālain, kitab Tafsīr Ibnu Kașìr, dan kitab tafsir lainnya. Sedangkan bi al-qalam artinya Al-Qur'an ditafsirkan dalam bentuk karya-karya tafsir.

\section{Resepsi Estetis}

Dalam resepsi ini, Al-Qur'an diposisikan sebagai teks yang bernilai estetis (indah), serta diterima dengan cara yang estetis pula. Resepsi ini berusaha menunjukkan keindahan inheren Al-Qur'an, antara lain melalui kajian puitik atau melodik yang terkandung dalam bahasa Al-Qur'an. Al-Qur'an diterima dengan cara yang estetis artinya Al-Qur'an dapat ditulis, dibaca, disuarakan, atau ditampilkan dengan cara yang estetik.

3. Resepsi Fungsional

Dalam model resepsi ini, Al-Qur'an diposisikan sebagai kitab yang ditujukan kepada manusia untuk dipergunakan demi tujuan tertentu. Maksudnya khițā b Al-Qur'an adalah manusia, baik karena merespon suatu kejadian atau karena mengarahkan manusia (humanistic hermeneutics) untuk melakukan sesuatu. Dari khițāb Al-Qur'an ini pula, manusia acapkali menggunakannya demi tujuan tertentu, baik tujuan normatif maupun praktis. Kemudian dari tujuan tersebut lahirlah sebuah dorongan untuk melahirkan sikap atau perilaku.

Resepsi fungsional terhadap Al-Qur'an dapat mewujud dalam fenomena sosial budaya di masyarakat dengan cara dibaca, disuarakan, diperdengarkan, ditulis, dipakai, atau ditempatkan. Tampilannya bisa berbentuk praktik komunal atau individual, rutin atau insidental, hingga mewujud dalam sistem sosial, adat, hukum, maupun politik. Tradisi seperti Yasinan adalah salah satu contoh konkret resepsi komunal-reguler. Begitu pula tradisi khataman Al-Qur'an di pesantren-pesantren dengan beragam variasi 
dan kreasinya merupakan salah satu contoh praktik komunal-insidental resepsi Qur'an di masyarakat.

Berangkat dari hal diatas, kemudian muncul pertanyaan, mengapa bisa muncul resepsi-resepsi sedemikian rupa yang kemudian melahirkan tradisi-tradisi? Hematnya, hal ini disebabkan oleh adanya dua alur pemahaman dalam tradisi Al-Qur'an. Dua alur ini adalah transmisi dan transformasi. Transmisi berarti pengalihan pengetahuan dan praktik dari generasi ke generasi, sedangkan transformasi berarti perubahan bentuk pengetahuan dan praktik sesuai kondisi masing-masing generasi. Contohnya tentang khasiat surat al-Fatihah, sebagaimana diriwayatkan oleh Abu Sa'̄̄d al-Khudrī, Rasulullah Saw. mengabarkan tentang fadìlah dari surat al-Fatihah. Pengetahuan ini ditransmisikan melalui rantaian mata sanad hadits dan tercantum dalam pelbagai riwayat. Informasi dari pelbagai riwayat tersebut kemudian ditransmisikan dari generasi ke generasi, hingga tercantum dalam Kitab Al-Tibyān fi Adab Hamalat Al-Qur'ān karya an-Nawawi, dalam bab tentang bacaan bagi orang sakit. Lalu muncul lagi dalam Kitab Khaz̄nat Al-Asrār dengan tata bacaan yang berbeda, namun idenya tetap sama berupa khasiat atau fậilah surat Al-Fatihah.

\section{Ragam Resepsi Al-Qur'an di Pondok Pesantren Al-Hidayah Karangsuci PURWOKERTO}

Sebagaimana pembahasan sebelumnya bahwa Ahmad Rafid membagi tipologi resepsi Al-Qur'an yang berkembang di masyarakat menjadi tiga. Ketiga tipologi tersebut adalah resepsi eksegesis, resepsi estetis, dan resepsi fungsional. Begitupun resepsi Al-Qur'an yang ada di Ponpes Al-Hidayah Karangsuci Purwokerto, diantaranya adalah: (1) Resepsi Eksegesis dalam pengajian Kitab Tafsir Jalālain, (2) Resepsi Estetis dalam Kaligrafi di Asrama Santri dan Ndalem Pengasuh, dan (3) Resepsi Fungsional Al-Qur'an dalam Tradisi Pembacaan Surat-Surat Pilihan.

Pengajian kitab Tafsīr Jalālain di Pondok Pesantren Al-Hidayah Karangsuci Purwokerto dilaksanakan setiap hari Senin sampai dengan hari Jum'at. Dimulai pada

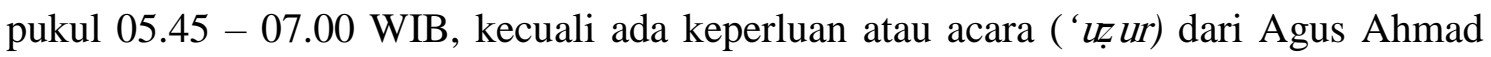
Arief Noeris selaku pengampu pengajian kitab tafsir tersebut. ${ }^{2}$ Pengajian tersebut didahului dengan membaca shalawat kalāmun qadímun secara bersama-sama sembari menunggu pengampu dan jama'ah yang belum hadir. Setelah pengampu hadir di lokasi, pengajian kemudian dibuka oleh pengampu dengan bersama-sama membaca surat alFatihah dan hadārah. Pengajian kitab Tafsir Jalalain di Ponpes Al-Hidayah Karangsuci

2 Wawancara dengan ust. Muhriz Jauhari pada Selasa, 13 Nopember 2018. 
berjalan dengan proses yang secara umum terdiri dari dua bagian pokok, yakni penjelasan tentang materi dan yang kedua menanggapi respon yang muncul dari jamaah. Bagian pokok yang pertama kemudian dijabarkan dalam tiga tahap proses.

Tahap yang pertama adalah pengasuh membacakan ayat-ayat Al-Qur'an yang akan dibahas. Sistem yang dipakai dalam pengajian ini adalah mengurutkan bacaan ayat demi ayat sesuai dengan urutan dalam mushāf ușmānī. Pada saat dilakukan observasi, pengampu membacakan QS. Al-Hujurat ayat 12 sampai dengan 13. Tahap yang kedua adalah penganpu memberikan makna kata pada ayat-ayat yang dibahas. Dalam memberikan makna, pengampu menggunakan bahasa jawa sesuai dengan i'rāa nya, sehingga jamaah lebih mudah dalam memahaminya.

Tahap yang ketiga adalah pengampu memberikan penjelasan tentang penafsiran ayat-ayat tersebut. Agus Ahmad Arief Noeris selaku pengampu, kerap kali menyampaikan beberapa keterangan tambahan terkait ayat yang sedang dibahas, seperti dengan cara menyampaikan al-Qiṣas ș wa at-Tārikh (penyampaian kisah-kisah dan sejarah), ataupun al-Istārah al Wijdāniyyah (pememberian stimulus kepada perasaanperasaan santri).

Setelah adanya pemaparan materi, pengampu biasanya menawarkan kepada forum untuk bertanya, apabila ada pertanyaan dari para jamaah, pengampu langsung merespon dengan menjawab pertanyaan-pertanyaan tersebut. Pengajian kitab Tafsir Jalalain di Ponpes Al-Hidayah Karangsuci ini kemudian diakhiri dengan salam dari pengampu dan diteruskan dengan membaca doa kafâ ratul majlis secara bersama-sama.

Selain itu, di Ponpes Al-Hidayah Karangsuci Purwokerto, kehadiran Al-Qur'an juga diresepsi secara estetis. Salah satu bentuk resepsi estetis tersebut ditemukannya ornamen-ornamen atau kaligrafi dari ayat suci Al-Qur'an di ndalem pengasuh, maupun asrama santri. Salah satu ayat Al-Qur'an yang ditampilkan di ndalem pengasuh adalah QS. Al-Hijr ayat 46.

Kaligrafi dari QS. Al-Hijr ayat 46 tersebut diletakkan di depan pintu menuju ke ndalem pengasuh, dengan ditulis dan dihias dengan berbagai ornamen dan iluminati. Garis batas atau iluminati yang digunakan adalah dengan menggunakan motif tumbuhan, dengan perpaduan warna yang sesuai, membuatnya semakin indah. Adapun kaligrafi dari ayat-ayat Al-Qur'an yang terdapat di asrama santri Ponpes Al-Hidayah Karangsuci Purwokerto, diantaranya adalah QS. Al-Ahzab ayat 21, dan QS. Al-kautsar ayat $1-3$.

Kedua kaligrafi penggalan ayat-ayat suci Al-Qur'an tersebut menggunakan model khat kufi. Adapun khat kufi merupakan salah satu bentuk tulisan yang paling dominan pada zaman dahulu (Faturrahman, 2018, p. 39). Khat dalam kaligrafi di Ponpes AlHidayah Karangsuci Purwokerto ini memiliki bentuk huruf yang proporsional kaku dan 
persegi. Dengan ukuran seimbang dan spesifiik serta sifatnya yang bersudut-sudut atau persegi menyolok, kaligrafi ini nampak indah serta memper-elok asrama santri putra di Ponpes Al-Hidayah Karangsuci.

Selain kedua bentuk resepsi diatas, di Ponpes Al-Hidayah Karangsuci para santri juga meresepsi kehadiran Al-Qur'an secara fungsional. Di antara implementasi resepsi Al-Qur'an secara fungsional tersebut adalah terdapatnya tradisi pembacaan Al-Qur'an surat-surat pilihan seperti QS. Al-Wāqi'ah, dan QS. Yāsin.

Pembacaan QS. Al-Waq'iah dilakukan rutin selepas melaksanakan shalat ashar, sedangkan pembacaan QS. Yāsin dilakukan rutin selepas melaksanakan shalat maghrib. Teknis dari kedua Tradisi hampir sama, yakni dengan didahului dengan membaca surat al-Fatihah dan hadarāh, membaca sayyid al-istighfär, dan membaca aurōd dengan bilangan tertentu. Kemudian dilanjutkan dengan membaca QS. Al-Waqi'ah atau QS. Yāsin, dan diakhiri dengan do'a.

Kedua Tradisi diatas, dipimpin oleh imam salat fardu berjamaah, yakni ustaz Nasrul Kholik. Jika beliau berhalangan menjadi imam shalat, maka imam badal atau pengganti yang lebih diutamakan adalah santri senior. Bagi yang menjadi imam badal imam shalat berjamaah, secara otomatis akan menjadi pemimpin dalam tradisi pembacaan Al-Qur'an surat $A l-W a q$ 'iah dan surat $Y$ ăsin tersebut. ${ }^{3}$

Di dalam tradisi pembacaan surat $A 1$-Waq'iah dan surat $Y \bar{a}$ sin tersebut, tidak menggunakan metode pembacaan tertentu - seperti pada masyarakat pada umumnya, yakni secara tartil dan benar serta dengan memperhatikan makhärij al-huruf serta bacaan yang sesuai dengan kaidah tajwidnya.

\section{Resepsi Eternalitas Al-Qur'an dalam Tradisi PenjagaAn Al-Qur'an: SEBUAH TEMUAN EPISTEMOLOGI BARU}

Dari ketiga tipologi resepsi Al-Qur'an yang disampaikan oleh Ahmad Rafiq (Rafiq, 2018), peneliti mendapati anomali ketika ketiga tipologi tersebut dihadapkan pada realitas resepsi Al-Qur'an di Ponpes Al-Hidayah Karangsuci Purwokerto-artinya tidak semua praktik resepsi Al-Qur'an di Ponpes tersebut terakomodasi oleh tiga tipologi yang dia ungkapkan. Adapun praktik un-acomodation yang peneliti maksud adalah adanya praktik preservasi Al-Qur'an yang terimplementasi dalam kegiatan setoran Al-Qur'an baik bi al-nazri maupun bi al-hifzi, kegiatan sima'an, dan kegiatan murāja'ah.

\footnotetext{
${ }^{3}$ Wawancara dengan ust. Muhriz Jauhari pada Kamis, 15 Nopember 2018.
} 
Praktik diatas merupakan contoh dari sekian banyak kegiatan pesantren yang bertujuan untuk menjaga otentisitas dan orisinalitas Al-Qur'an, dengan berikhtiar membentuk mental serta jiwa qur'ani bagi seluruh santri. Seiring dengan berjalannya waktu, dalam rangka syiar Qur'ani, diselenggarakan pula pemberian syāhadah bagi mereka yang telah mengkhatamkan Al-Qur'an, baik bi al-hiffz maupun bi an-nazri. Acara ini kemudian dipadukan dengan peringatan tahun baru Islam atau muharrām.

Praktik presevasi Al-Qur'an memang seolah 'lebih dekat' kepada resepsi fungsional, akan tetapi, hal membedakannya dengan resepsi fungsional ini adalah apabila dalam resepsi fungsional, seorang peresepsi mengharapkan adanya 'income' atau 'feedback' yang didapatkannya setelah meresepsi Al-Qur'an, ${ }^{4}$ sedangkan dalam praktik preservasi Al-Qur'an tidak.

Hal tersebut diataslah yang menjadi asumsi dasar peneliti guna memunculkan tipologi resepsi Al-Qur'an yang ke-empat guna mengakomodasi praktik preservasi tersebut. Tipologi resepsi Al-Qur'an keempat ini, peneliti sebut dengan resepsi eternalitas Al-Qur'an, yang berarti respon masyarakat terhadap kehadiran Al-Qur'an yang bertujuan untuk menjaga keotentikan, keorisinalitas, dan keabadian Al-Qur'an baik dengan cara dibaca bi al-lisān atau ditulis bi al-qaläm.

\section{E. Makna Resepsi Al-Qur'an Di Pondok Pesantren Al-Hidayah KarangSuCi PURWokerto}

Untuk bisa mengungkap makna yang melekat dalam ragam resepsi Al-Qur'an di Ponpes Al-Hidayah Karangsuci Purwokerto, peneliti menggunakan teori sosiologi makna Karl Mannheim sebagai pisau analisis. Menurut Karl Mannheim, di dalam sebuah perilaku seseorang, terdapat tiga makna yang melekat di dalamnya. Maknamakna tersebut antara lain makna objektif, makna eskpresif, dan makna dokumenter. Makna objektif, adalah makna yang ditemukan oleh konteks sosial dimana tindakan tersebut berlangsung. Makna ekspresif adalah makna yang ditunjukkan secara personal oleh aktor yang terintegrasi dalam sebuah tradisi atau praktik. Sedangkan makna dokumenter adalah makna yang dari suatu tindakan, sehingga dikarenakan makna yang tersirat tersebut, seorang aktor atau pelaku tindakan tersebut tidak sepenuhnya

${ }^{4}$ Sebagaimana praktik pengobatan menggunakan media air dengan dibacakan surat al-Fātihah, bertujuan didapatkannya kesembuhan atas sakit yang diderita. Harapan adanya income atau feedback juga dirasakan oleh peresepsi Al-Qur'an yang mentradisikan membaca surat-surat pilihan. Dengan rutin membaca surat $A$ l-Wäqi'ah menginginkan agar dirinya dijauhkan dari kefakiran, dan musibah. Lihat (Mustaqim, 2007, p. 3). 
menyadari bahwa praktik yang diekspresikannya adalah menunjukkan kepada budaya secara keseluruhan (Baum, 1999, pp. 15-16).

\section{Makna Objektif}

Makna objektif yang terdapat dalam ragam resepsi Al-Qur'an di Ponpes AlHidayah Karangsuci Purwokerto adalah sebagai simbolisasi kepatuhan atau ketakziman terhadap peraturan pondok yang ditetapkan, maupun arahan-arahan yang diberikan. Sikap hormat, takzim, dan kepatuhan mutlak kepada guru inilah yang menjadi ciri khas dari pesantren. Maka dari itu tidak mengherankan, apabila Syamsul Ma'arif mengatakan bahwa pesantren merupakan tempat yang digunakan para kiai untuk membangun pola patronasenya (Ma'arif, 2010, p. 277). Dari pola patronase inilah, pesantren sebagai lembaga pendidikan menunjukkan kepada kita, bahwa ia mampu bertahan dan survive sampai dengan sekarang.

Dalam pengajian kitab tafsir jalalain misalnya, merupakan salah satu kegiatan yang bersifat wajib bagi santri yang sudah lulus setoran 30 juz bi al-nazri dan santri yang sudah mencapai kelas 'Aliyah. ${ }^{5}$ Dalam hasil wawancara dengan santri yang tergabung dalam pengajian tafsir tersebut, tidak sedikit dari mereka yang melakukan kegiatan tersebut sebagai bentuk kepatuhan terhadap peraturan Pondok Pesantren. Sikap hormat, patuh, dan takzim terhadap peraturan inilah yang menjadi salah satu nilai pertama yang ditanamkan pada setiap santri. ${ }^{6}$ Akhlak yang dibangun adalah bagaimana para santri dapat menghormati seorang guru. Sosok seorang guru ini kemudian digambarkan sebagai sosok pewaris Nabi, al-'ulamā warasat al-anbiyā. Hal ini lah yang kemudian menjadi pandangan hidup santri, dimana setiap perbuatan seyogyanya mendapat restu dari pengasuh, dan berusaha untuk tidak melakukan perbuatanperbuatan yang tidak dalam rida-nya. Hal ini pula lah yang kemudian pembentuk habitus santri dalam melakukan kegiatan pengajian Kitab Tafsir Jalalain, dalam rangka menjalankan sebuah sistem konsep yang sudah mereka yakini.

Skema. 1. Pemaknaan Objektif dalam relasi patron-klien antara pengasuh/asātiz dan santri

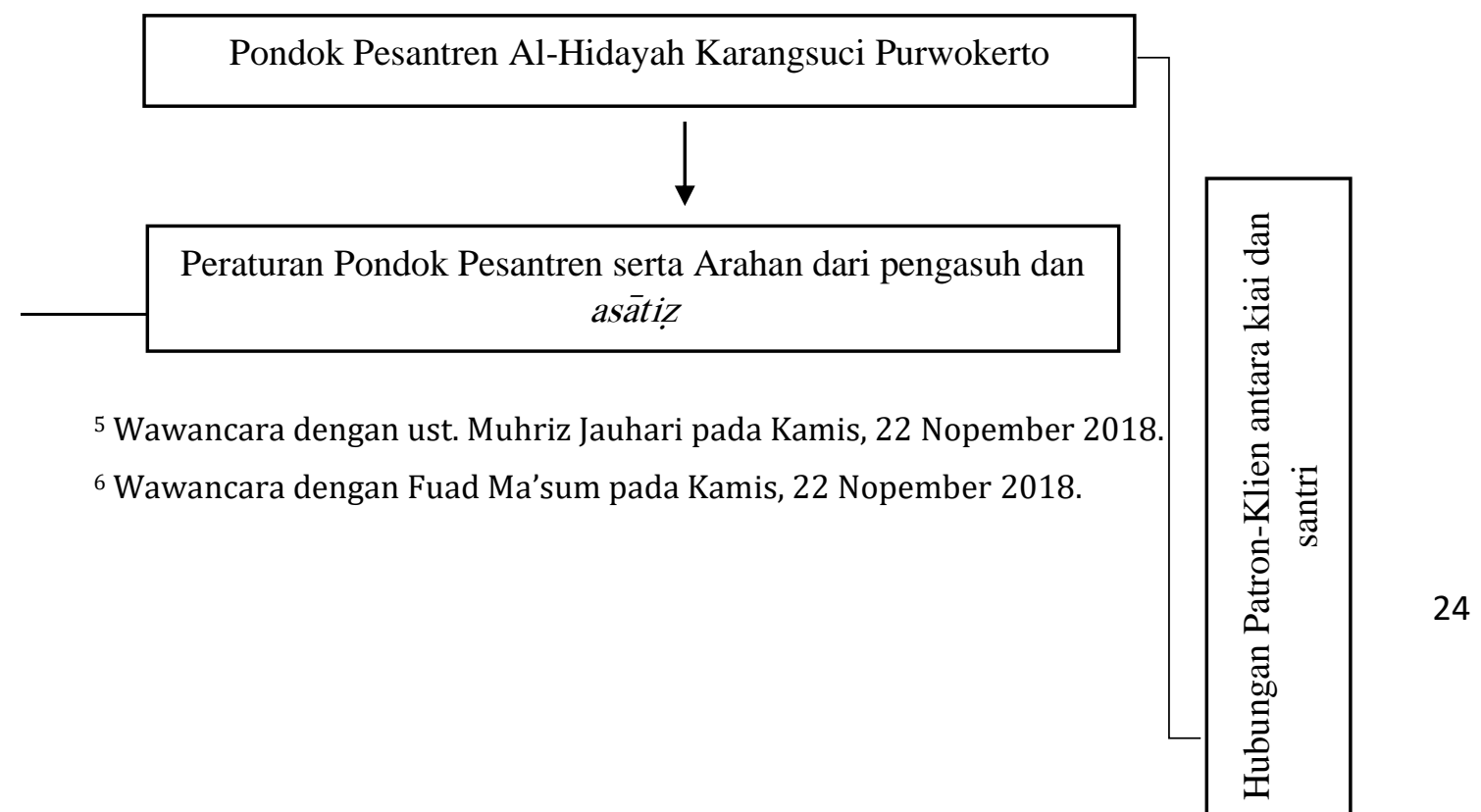




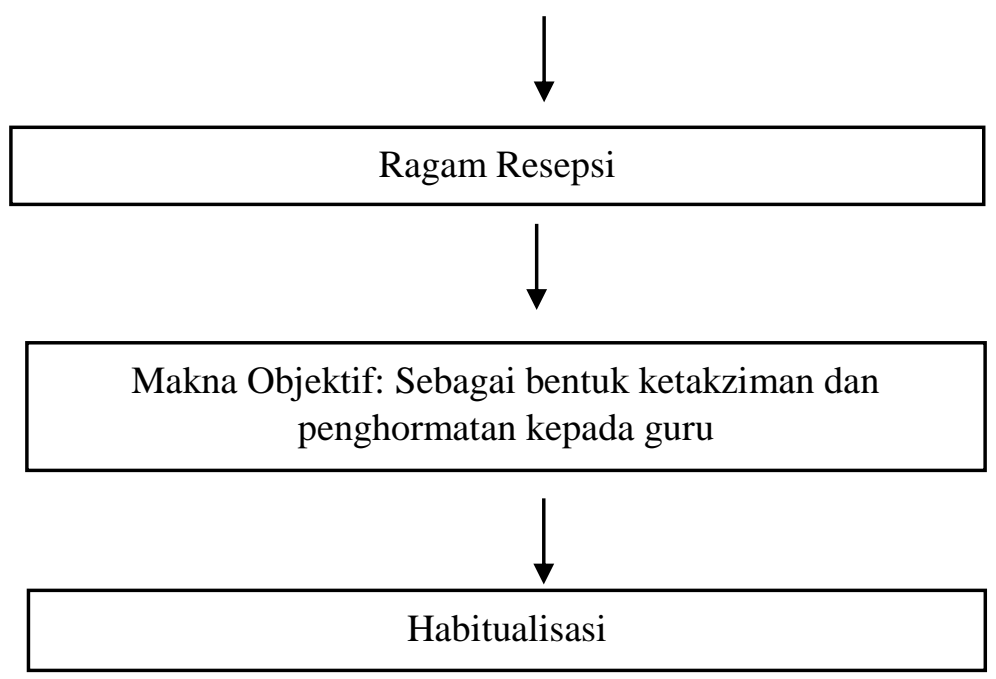

\section{Makna Ekspresif}

Dari ragam resepsi Al-Qur'an yang ada di Ponpes Al-Hidayah Karangsuci Purwokerto, makna ekspresif yang ditunjukkan oleh para aktor berbeda-beda. Dalam pengajian kitab Tafsir Jalalain misalnya, makna ekspresif yang dimunculkan oleh santri antara lain: (a) menambah khazanah keilmuan mereka terhadap penafsiran ayat-ayat AlQur'an, (b) sebagai bentuk ikhtiar guna menjadi sebaik-baik manusia, dan (3) menghindari kesombongan, karena bagi mereka boleh tidak mengaji apabila sudah pintar, selagi belum pintar maka harus terus mengaji. ${ }^{7}$

Kemudian bagi pengampu, pengkajian Kitab Tafsir Jalalain ini diekspresikan sebagai bentuk pengapresiasian terhadap karya-karya yang dihasilkan oleh ulama-ulama klasik. ${ }^{8}$ Beliau berpandangan bahwa tafsir merupakan salah satu diskursus ilmu yang penting dipahami oleh para santri, karena dengan memahami penafsiran-penafsiran AlQur'an, santri akan dapat membuka tabir rahasia makna-makna Al-Qur'an, baik yang terkait konsep 'ubüdiyah maupun mu'āmalah. Dengan adanya pemahaman tersebut, santri akan memiliki dasar yang kokoh untuk mencapai kebahagiaan yang hakiki, sehingga kompetensi apapun yang berorientasi pada hal-hal yang profanik (duniawi) maupun eskatologik (ukhrawi), secara langsung bergantung pada equilibrium pemahaman mereka terhadap makna yang terkandung dalam Al-Qur'an. ${ }^{9}$ Makna Ekspresif dalam Resepsi Estetis Al-Qur'an.

\footnotetext{
7 Wawancara dengan Saifuddin pada pada Jum'at, 23 Nopember 2018.

8 Wawancara dengan Agus Ahmad Arief Noeris pada Kamis, 22 Nopember 2018.

9 Wawancara dengan Agus Ahmad Arief Noeris pada Minggu, 18 Nopember 2018.
} 
Kemudian dalam resepsi estetis Al-Qur'an yang terimplementasi dalam kaligrafi yang terdapat di asrama santri ataupun ndalem pengasuh, diekspresikan sebagai bentuk simbolisasi spiritual-maksudnya kaligrafi yang ditampilkan tidak hanya bernilai keindahan, tetapi yang terpenting adalah dalam rangka memberikan pencerahan kepada seseorang yang membaca. Artinya ketika seorang melihat ayat tersebut, maka hatinya akan tergugah, seakan-akan ayat tersebut memberikan peringatan kepada pembaca. ${ }^{10}$ Hal ini dapat dilihat dari ditampilkannya kaligrafi QS. Al-Kautsar ayat 1 sampai dengan 3 di asrama santri adalah sebagai upaya pengingat akan pentingnya bersyukur atas nikmat yang diberikan, istiqomah dalam melakukan perintah shalat dan tidak lupa berkorban sebagai simbol kepedulian sosial. Selain itu QS. Al-Ahzab ayat 21 yang berbunyi laqod kāna lakum fỉ rasūlillāhi uswatun hasanah, ditampilkan oleh para santri sebagai upaya pencerahan untuk meneladani dan mengambil hikmah dari sikap hidup yang dicontohkan Rasulullah Saw.

\section{Makna Dokumenter}

Makna dokumenter dapat diartikan sebagai maka yang tersirat atau tersembunyi dari suatu tindakan, sehingga dikarenakan makna yang tersembunyi tersebut, seorang aktor atau pelaku tindakan tidak sepenuhnya menyadari bahwa aspek yang diekspresikan menunjukkan kepada budaya yang menyeluruh. Beberapa ahli mengatakan bahwa makna dokumenter ini dapat diperoleh dari analisa yang mendalam dengan kajian ekstra teoritis.

Dari ragam resepsi Al-Qur'an di Ponpes Al-Hidayah Karangsuci Purwokerto, dapat diketahui bahwa ragam resepsi tersebut merupakan suatu kebudayaan yang menyeluruh. Dalam Pengajian kitab Tafsir Jalalain misalnya, dari wawancara yang dilakukan, disampaikan keterangan bahwa alasan terkait diadakannya kegiatan tersebut adalah sebagai upaya menjaga tradisi yang sudah turun temurun. Hal ini secara tidak langsung, pelaku resepsi mengafirmasi terhadap pandangan kalangan pesantren terkait hakikat ilmu. Sebagaimana penah ditulis oleh F. Mas'udi bahwa bagi masyarakat pesantren, ilmu adalah sesuatu yang hanya dapat diperoleh melalui jalan pengalihan, pewarisan, transmisi, dan bukan sesuatu yang bisa diciptakan (Anwar, 2016, p. 59).

Berangkat dari pandangan tersebut, ada dua konsekuensi logis yang dihasilkan, yang pertama adalah keseragaman dan yang kedua adalah stratifikasi keilmuan. Keseragaman atau homogenitas ini dapat dilihat dari banyaknya lembaga pendidikan pesantren yang mengkaji kitab Tafsir Jalalain ini. Kalau saja terjadi perbedaan, hampir bisa dipastikan hanya dalam pengungkapan ('ibrah)-nya saja. Kemudian tentang

10 Wawancara dengan Ibu Nyai Dra. Hj. Nadhiroh pada Jum'at 23 Nopember 2018. 
stratifikasi keilmuan, kitab Tafsir Jalalain sebagai salah satu karya ulama terdahulu kemudian menjadi bersifat sentral, sementara kiai yang memberikan keterangan dari kitab tersebut, hanyalah sebagai subordinat atau sekedar instrumen, sehingga tidak berhak di dalam memberikan pengevaluasian (Anwar, 2016, p. 59).

Dengan demikian menjadi suatu yang benar adanya, apabila pengajian Kitab Tafsir Jalalain di Ponpes Al-Hidayah Karangsuci Purwokerto merupakan suatu kebudayaan yang menyeluruh, artinya pengajian tafsir yang dilakukan merupakan salah satu bentuk kebudayaan dari kebudayaan-kebudayaan yang lain, dimana kebudayaan ini sudah ada sejak zaman dahulu sebagaimana yang dilakukan oleh pengarang Kitab Tafsir Jalalain itu sendiri.

Kemudian di dalam resepsi estetis Al-Qur'an di Pontren Al-Hidayah Karangsuci Purwokerto misalnnya, dapat dikatakan sebagai suatu sistem kebudayaan yang menyeluruh. Hal ini tentunya tidak banyak didasari oleh para pelaku resepsi, bahwa seni semacam ini tentunya sudah ada sejak zaman dahulu (Rispul, 2012, p. 11). Terdapat banyak pendapat terkait asal-usul mengenai seni kaligrafi, sebagian mendasarkan dari data-data historis yang bisa dilacak dan diuji validitasnya, sebagian lagi mendasarkan pada keyakinan-keyakinan mistis yang kerap tidak terang ujung-pangkalnya. Namun demikian, dapat ditarik kesimpulan bahwa tulisan kaligrafi tidak tercipta secara mendadak pada satu kesempatan dalam keadaan yang sempurna, melainkan tumbuh melalui proses panjang secara berangsur-angsur. Setiap jenis tulisan berproses melalui eksperimentasi dan intensifikasi selama bertahun-tahun dan berkurun-kurun sampai kemudian membentuk tulisan yang sekarang, bahkan selalu berkembang.

Disamping itu, kaligrafi yang bersumber dari ayat-ayat suci Al-Qur'an dalam proses transformasinya menjadi suatu karya seni, tidak hanya mengandung unsur keindahan bentuk visualnya saja, tetapi juga makna-makna dalam ayat Al-Qur'an yang menggambarkan firman Allah Swt. sebagai kalam ilahi. Oleh karena ayat-ayat AlQur'an merupakan suatu kekuatan dan mukjizat, maka huruf dan kata-kata yang menvisualisasikan ayat-ayat Al-Qur'an juga memerankan suatu mukjizat dan memperlihatkan kekuatan-kekuatannya sendiri dalam sebuah karya seni, sehingga akan melahirkan karya seni dengan muatan-muatan yang ingin disampaikan.

Kemudian dalam praktik preservasi Al-Qur'an yang dilakukan oleh santri Ponpes Al-Hidayah sebenarnya juga merupakan suatu kebudayaan yang menyeluruh. Bentuk paling awal misalnya dapat dilihat dari periwayatannya, dimana para sahabat Nabi Saw. berusaha untuk "menjaga" Al-Qur'an dengan cara dihafal. Beberapa sahabat yang terkenal dalam periwayatan Al-Qur'an ialah Zaid bin Tsabit, Ali bin Abi Thalib, Ibn Abbas, dan Usman bin Affan. Secara umum, seperti yang disebutkan oleh Khalil Jum'ah bahwa seluruh sahabat Nabi Saw. mayoritas hafal Al-Qur'an (Lubis, 2017, p. 
68). Keuletan para sahabat dalam menghafal Al-Qur'an inilah yang menjadi cikal bakal pengkodifikasian Al-Qur'an secara tekstual amal.

Salah satu nilai terpenting yang dapat diambil dari historikal penyebaran AlQur'an pada generasi awal diatas adalah Al-Qur'an sejatinya diriwayatkan melalui hafalan, walaupun ada beberapa sahabat yang mencoba untuk menuliskan Al-Qur'an, namun pola seperti ini tidak menjadi tradisi muslim Arab kala itu. Kemudian pasca Rasulullah Saw. wafat, meskipun Al-Qur'an selesai dikodifikasi menjadi sebuah naskah tekstual, teapi tradisi menghafal Al-Qur'an di kalangan umat islam masih terus dilakukan. Hal ini dibuktikan dengan banyaknya penghafal Al-Qur'an yang muncul pada masa täbi'in, tabi tābi'in, dan generasi salaf, bahkan sampai saat ini umat Islam masih terus menghafal Al-Qur'an sebagaimana praktik resepsi eternalitas Al-Qur'an yang ada di Ponpes Al-Hidayah Karangsuci Purwokerto.

Sebagai suatu sistem kebudayaan yang menyeluruh, praktik resepsi eternalitas AlQur'an di Ponpes Al-Hidayah Karangsuci Purwokerto memilki arti bahwa ia adalah satu bentuk dari ragam bentuk budaya yang lain. Sebagai contoh adalah resepsi eternalitas Al-Qur'an melalui hafalan dan khataman A1-Qur'an di Subang, Propinsi Jawa Barat. Di Jawa Barat terdapat tradisi Sisingaan yang para penghafal Al-Qur'an diarak pada saat khataman Al-Qur'an, kemudian di Banjar terdapat Tradisi Payung Kembang, kemudian di pesantren-pesantren lain juga terdapat prosesi wisuda ketika santri selesai mengkhatamkan hafalan Al-Qur'an.

Ragam praktik eternalitas Al-Qur'an di era sekarang tentunya sangat berbeda dengan praktik eternalitas Al-Qur'an di masa awal generasi Islam. Di masa generasi Islam, bentuk praktiknya masih sangat sederhana, kemudian pengetahuan tentang praktik eternalitas Al-Qur'an ini ditransmisikan melewati ruang dan waktu, sekaligus mengalami transformasi terhadap bentuk resepsi eternalitas Al-Qur'an itu sendiri. Hingga jadilah pada saat ini bentuk-bentuk yang berbeda namun bermuatan sama. Inilah kemudian yang menjadi legitimasi bahwa praktik eternalitas Al-Qur'an di Ponpes AlHidayah Karangsuci merupakan suatu kebudayaan yang menyeluruh.

\section{Skema 2. Makna dokumenter dalam Resepsi Al-Qur'an di Ponpes Al-Hidayah Karangsuci Purwokerto (kontekstualisasi lokal sebagai unit dari kebudayaan yang menyeluruh)}

Resepsi Al-Qur'an masa awal generasi Islam: Rasulullah Saw.

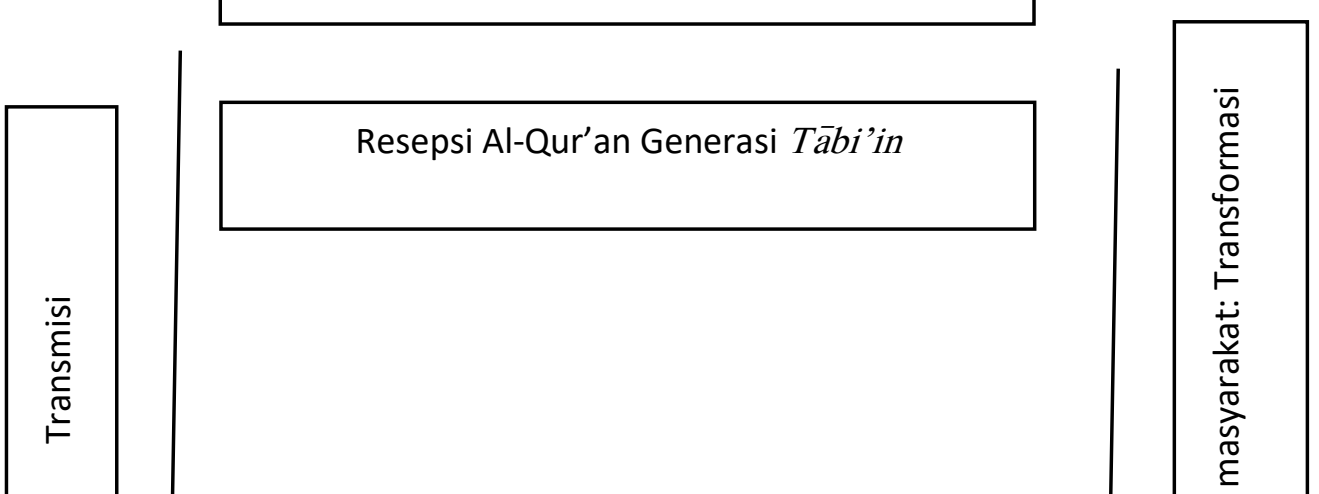


Resepsi Al-Qur'an Generasi Täbi'in at-täbi'in

Resepsi Al-Qur'an Generasi ulama klasik

Resepsi Al-Qur'an Generasi ulama kontemporer: ragam resepsi Al-Qur'an di Ponpes Al-Hidayah Karangsuci Purwokerto, dst.

\section{F. Simpulan}

Berdasarkan penelitian yang dilakukan mengenai praktik-praktik Resepsi AlQur'an di Ponpes Al-Hidayah Karangsuci Purwokerto dengan mengumpulkan data dari berbagai sumber, kemudian sajikan dan dianalisis berdasarkan instrumen yang digunakan, maka dapat peneliti simpulkan sebagai berikut: (1) Ragam praktik-praktik resepsi Al-Qur'an yang ada di Pontren tersebut terbagi menjadi empat ragam. Empat ragam yang penulis maksud adalah: (a) resepsi eksegesis yang termanifestasikan dalam kegiatan pengajian kitab Tafsir Jalalain, (b) resepsi estetis dalam kaligrafi yang menukil ayat-ayat Al-Qur'an baik yang bertempat di asrama santri atau ndalem pengasuh, (c) resepsi fungsioanl yang terwujud dalam tradisi pembacaan surat-surat pilihan - alwaqi'ah dan yasin, serta (d) resepsi eternalitas Al-Qur'an yang termanifestasikan dalam beragam kegiatan penjagaan Al-Qur'an, baik hafalan, setoran maupun muräja'ah AlQur'an; (2) Makna yang melekat dari ragam resepsi Al-Qur'an yang ada di Ponpes AlHidayah Karangsuci Purwokerto tersebut, peneliti membaginya menjadi tiga makna. Tiga makna yang peneliti maksud yakni makna objektif, makna ekspresif, dan makna dokumenter. Makna objektif menyimpulkan bahwa ragam perilaku resepsi di ponpes tersebut adalah simbolisasi dari ketakziman dan kepatuhan terhadap peraturan pondok. Sedangkan makna ekspresifnya adalah sebagai wujud internalisasi diri dengan hal-hal positif melalui proses pembelajaran Al-Qur'an yang berkelanjutan, dan makna dokumenternya adalah sebagai bentuk kontekstualisasi lokal dari sistem kebudayaan yang menyeluruh. Makna-makna yang terdapat dalam ragam resepsi Al-Qur'an tersebut merupakan indikator konkret bahwa Al-Qur'an merupakan kitab suci yang selaras 
dengan zaman, lintas tempat, ras, suku, dan bangsa (sālịh li kulli zamān wa makān), serta sebagai bukti adanya struktur logika pragmatis tentang kemukjizatan Al-Qur'an.

Penelitian ini merupakan penelitian terhadap ragam resepsi Al-Qur'an yang ada di Ponpes Al-Hidayah Karangsuci Purwokerto, selain meresepsi Al-Qur'an dalam berbagai ragam bentuk diatas, para santri dan pengasuh juga melakukan resepsi terhadap teks-teks hadis. Dengan demikian, peneliti selanjutnya dapat melanjutkan penelitian terhadap hadis-hadis yang diresepsi oleh santri dan pengasuh Ponpes AlHidayah Karangsuci Purwokerto melalui pendekatan lain yang ditentukan oleh ketertarikan personal dari peneliti.

\section{G. DAFTAR PUSTAKA}

Al-Baihāqī. (1408). Dalāil al-Nubuwwah. Kairo: Dār al-Kutb al-'Ilmiyyah.

Anwar, R. (2016). Kajian Kitab Tafsir dalam Jaringan Pesantren di Jawa Barat. Jurnal Wawasan, 1(1), 59.

Baum, G. (1999). Agama dalam Bayang-Bayang Relativisme: Agama, Kebenaran dan Sosiologi Pengetahuan (A. M. Chaeri \& A. Arow, Trans.). Yogyakarta: PT. Tiara Wacana Yogya.

Fathurrosyid, F. (2015). Tipologi Ideologi Resepsi Al-Qur'an di Kalangan Masyarakat Sumenep Madura. Jurnal El-Harakah, 12(2).

Faturrahman, I. (2018). Pengenalan Pola Huruf Hijaiyah Khat Kufi dengan Metode Deteksi Tepi Sobel Berbasis Jaringan Syaraf Tiruan Backpropagation. Teknik Informatika, 11(1).

Iser, W. (1978). The Act of Reading; A Theory of Aesthetic Response. Baltimore: John Hopkins University Press.

Iswatunnisa, K. (2015). Keserasian Bunyi Akhir dalam Al-Qur'an Surah Al-Insyirah (Kajian Aspek Fonologi Terhadap Al-Qur’an) (Skripsi). Fakultas Ushuluddin dan Pemikiran Islam UIN Sunan Kalijaga, Yogyakarta.

Lubis, M. H. (2017). Efektivitas Pembelajaran Tahfizhil Qur'an dalam Meningkatkan Hafalan Santri di Islamic Centre Sumatera Utara. Jurnal Ansiru PAI, 1(2), 68.

Ma'arif, S. (2010). Pola Hubungan Patron-Client Kiai dan Santri di Pesantren. Junral Ta'dib, XV(2).

Mustaqim, A. (2007). Metodologi Penelitian Living Qur'an dan Hadis. Yogyakarta: TH-Press. 
Pradopo, R. D. (2007). Beberapa Teori Sastra; Metode Kritik dan Penerapannya. Yogyakarta: Pustaka Pelajar.

Rafiq, A. (2004). Pembacaan yang Atomistik terhadap Al-Qur'an: Antara Penyimpangan dan Fungsi. Jurnal Studi Ilmu-Ilmu Al-Qur'an Dan Hadis, 5(1).

Rafiq, A. (2018, Kamis, Oktober). Tradisi Resepsi Al-Qur'an di Indonesia. Retrieved from Sarbini damai website: sarbinidamai.blogspot.com

Ratna, N. K. (2009). Teori, Metode, dan Teknik Penelitian Sastra. Yogyakarta: Pustaka Pelajar.

Rispul. (2012). Kaligrafi Arab sebagai Karya Seni. Jurnal Tsaqafa, 1(1), 11.

Sudarmoko, I. (2016). The Living Qur'an: Studi Kasus Tradisi Sema'an Al-Qur'an Sabtu Legi di Masyarakat Sooko Ponorogo (Tesis). UIN Maulana Malik Ibrahim, Malang.

Wahid, M. A. (2016). Tafsir Liberatif Farid Esack. Tafsere, 4(2). 